YAN Shimei, YAN Shizhi, ZHANG Man

\title{
Manifestation of gender discrimination in the process of human resources development -A content analysis based on interview data
}

\author{
(C) Higher Education Press and Springer-Verlag 2009
}

\begin{abstract}
This study focuses on the issue of gender discrimination manifested in the process of human resources development (HRD). A theoretical model is developed based on prior literature. Scenarios of gender discrimination in enterprises are obtained from in-depth interviews. Results of content analysis indicate that gender discrimination in HRD have four forms of manifestation, namely occupational gender segregation, employment gender discrimination, glass ceiling, and gender salary discrimination. Compared with top and middle-level managers, employees can perceive more employment-related gender discrimination and less glass ceiling. There is no significant difference between female and male in the above four manifestations. Compared with other types of enterprises, gender salary discrimination is more likely to happen in private enterprises, and occupational gender segregation and glass ceiling are more prevalent in foreign funded enterprises. It is also found that gender discrimination often occurs at the stage of job arrangement in the process of HRD.
\end{abstract}

Keywords human resource development, employment gender discrimination, occupational gender segregation, glass ceiling, gender salary discrimination,

Translated and revised from Guanli Shijie 管理世界 (Management World), 2008, (11): $110-118$

YAN Shimei $(\bowtie)$

Management School, Zhejiang University, Hangzhou 310058, China

E-mail: shimeiyan@zju.edu.cn

YAN Shizhi

School of Law and Politics, Zhejiang Sci-Tech University, Hangzhou 310058, China

E-mail: shizhiyan2008@126.com

ZHANG Man

Management School, Zhejiang University, Hangzhou 310058, China

E-mail: zhangman0822@sina.com 
content analysis method

摘要 聚焦在企业人力资源开发中性别歧视的表现形式问题, 先基于以往文献构建 了人力资源开发中性别歧视表现形式的理论模型; 然后, 通过深度访谈法获取企业性 别歧视的情景性资料, 运用内容分析技术结构化地分析资料来验证模型。研究发现, 企业人力资源开发中性别歧视主要表现在雇佣性别歧视、职业性别隔离、玻璃天花板 和薪酬性别歧视四个方面; 并且相对于高层和中层, 低层职员往往会更多地感知到 雇佣性别歧视, 而更少地感知到玻璃天花板; 男性与女性职员在性别歧视四种表现 形式的感知上不存在显著差异; 相对于其它类型企业而言, 民营企业更可能产生薪 酬歧视问题, 外 (合) 资企业更容易出现职业性别隔离和玻璃天花板现象; 相对于 其它人力资源开发阶段, 在工作安排阶段, 更容易出现各种性别歧视现象。

关键词人力资源开发, 雇佣性别歧视, 职业性别隔离, 玻璃天花板, 薪酬性别歧视, 内容分析方法

\section{Introduction}

Gender equality, particularly in the economic sense, is a key issue in the building of a "harmonious society" because economic status is a decisive factor of measuring and evaluating female's social status. As the basic unit of social economy, business enterprises offer unique research perspective to investigate gender equality and discrimination. Based on the above, this study attempts to explore gender discrimination in the process of HRD in enterprises.

Extant literature on gender discrimination can be divided into two streams. One focuses on the glass ceiling in promotion, employment gender discrimination, occupational gender segregation, gender salary discrimination and difference, and reasons of gender discrimination. As a whole, studies in this stream are short of specific analysis on various manifestations of gender discrimination. The other research stream studies gender discrimination issue in the context of organizations or enterprises. For example, after analyzing the studies on gender differences in world top managerial and psychological magazines, Ely and Padavic (2007) found that out of 131 studies on gender equality, only $17 \%$ associated empirical analysis process with organization and $12 \%$ put the empirical analysis process into the context of organization. Besides, relevant previous studies attached little importance to analysis of gender discrimination in different types of enterprises. However, with the increase of private enterprises in transitional Chinese economy, researchers have paid greater attention to the difference between stated-owned and private enterprises. Liu and Meng (2000) found that the salary gap between male and female employees has 
declined substantially in state-owned and private enterprises alike. The increase in gender salary gap due to marketization is much larger than any increase in differential that may arise from more gender discrimination. Long (1975) believed that public sector is comparatively a "low" discriminator or a nondiscriminator due to the constraints of numerous bureaucratic rules and regulations designed to insure nondiscriminatory hiring and promoting of public employees.

Therefore, this study will place gender discrimination issue into the context of HRD in business, with a concrete analysis on manifestation of gender discrimination in the different types of enterprises. Exploring such an issue can lay a solid foundation to further analyze the degree of gender discrimination in HRD and eliminate gender discrimination in the end. According to the argument of Heery and Noon (2001), the process of enterprise HRD is defined as an enterprise's encouragement to its employees to acquire new knowledge and skills through various training programs, training courses and learning arrangement. As for employees, HRD provides lots of opportunities, such as improving job stability, providing more in-organizational career development opportunities and enhancing the employee's out-organizational employability. Yang (1997) pointed out that HRD is to give full play of employee's potential through various HR practices, such as recruitment, training, promotion, salary management and cultural construction, so as to enable them to achieve organization goals. Therefore, enterprise HRD is a process of recruiting and promoting employees to realize organization goals. It refers to the several stages in HR management, including recruitment, job arrangement, training, salary management and performance evaluation. Gender discrimination in HRD means that HR management decisions (e.g., recruitment, evaluation, promotion and salary decision) are based on people's attributable characteristics, such as physiological gender and social gender, rather than basing on individual qualification and job performance (Gutek et al., 1996; Ngo et al., 2002). The gender discrimination in this study refers to gender discrimination to female employees.

In order to make clear the specific gender discrimination in HRD and its manifestation in different enterprise types and at different HRD stages, we first develop a theoretical model of manifestation for gender discrimination in HRD based on previous studies. Then, we introduce scenarios of gender discrimination in enterprises by in-depth interviews. Finally, scenarios are analyzed with content analysis method to verify the model.

\section{A model of gender discrimination in HRD}

Due to the lack of direct research on manifestation of gender discrimination in the prior studies, this study aims at reviewing and expanding present gender discrimination 
studies in order to develop a model of manifestation of gender discrimination in HRD.

Gutek et al. (1996) used three items to measure gender discrimination perceived in an organization, namely promotion discrimination, employment discrimination and permanent position acquirement discrimination. According to Haberfeld's (1992) model of organizational employment gender discrimination, gender discrimination in organization includes employment discrimination, job arrangement discrimination and salary discrimination. Jacobs (1993) introduced another item of gender inequality - occupational gender segregation, while Yamagata et al. (1997) found that occupational gender segregation and glass ceiling are always the most common items of gender inequality in the workplace of their analysis on gender discrimination in internal labor market. Li and Zhao (1999) argued that gender discrimination in labor market is embodied as occupational discrimination and salary discrimination. From the perspective of organization or internal labor market, occupational discrimination is equal to occupational gender segregation in very much the same way salary discrimination to salary gender discrimination. Petersen and Togstad (2006) argued that there are lots of gender discrimination behaviors leading to gender differences in internal labor market, containing salary discrimination, employment discrimination, promotion discrimination, and so on. Based on these studies, this study assumes that gender discrimination in organization runs throughout the whole process of HR management practices, such as recruitment, job arrangement, promotion and salary management, etc. Specifically, gender discrimination in an organization has four subtypes, namely employment gender discrimination, occupational gender segregation, glass ceiling in the promotion and salary gender discrimination. The same result can be acquired by searching and summarizing relevant gender discrimination studies in organization HRD. Besides, previous studies also help to gain a better understanding of these forms of gender discrimination at work.

\subsection{Employment gender discrimination}

As the primary stage of $\mathrm{HRD}$, employee recruitment is an important step because it affects organization HR distribution and development to a certain degree. Hence, employment gender discrimination will have great impact on female HRD. Based on the argument of Bellizzi and Hasty (2000), employment gender discrimination in HRD means employment decision is made on the basis of certain gender characteristics, rather than on the basis of recruitment requirements. As we can see, employment decision refers to two parts: one is to employ an applicant or not; the other is what kind of position shall be arranged for the new employee. The manifestation of gender discrimination of the former one is that female applicants are more likely to be denied because of their 
physiological and social gender characteristics, even though these female applicants are qualified for the job. The latter one is that new female employees are more likely to obtain positions ranking lower than their capabilities. In this paper, employment gender discrimination refers to the former because in HRD, recruitment process is usually standardized. Therefore, when recruiting people for a certain position, the recruitment decision is usually a yes or no one. It is certain that employment gender discrimination will result in position discrimination and occupational gender segregation from the view of external labor market. However, from the view of internal labor market or individual level in enterprises, employment discrimination will influence talent acquisition, rather than induce occupational gender segregation directly. Therefore, the later should be reflected in another HR management practice, such as position arrangement, which directly leads to occupational gender segregation.

\subsection{Occupational gender segregation}

Occupational gender segregation has always been a focus in gender discrimination studies, which mainly concerns why female are excluded from some positions representing high prestige, technology requirement and salary (Wang, 2004).The more gender segregation positions in a society, the larger occupational gender differences and the more serious the phenomenon of occupational gender inequality (Cai and $\mathrm{Wu}, 2002$ ). From the perspective of external labor market, Cai and $\mathrm{Wu}$ (2002) and Zhu et al. (2003) considered the occupational gender segregation as the probability of different gender getting into certain kind of occupations and industries. While the proportion of male and female in a certain occupation is the same as employment proportion in a society, it implies no occupational gender segregation, however, if the former exceeds the latter, it implies the existence of occupational gender segregation. These scholars emphasized gender distribution features in a certain occupation and industry. However, Jacobs (1993) argued that, besides distribution features, process features are also manifestations of occupational gender segregation. Hence, he introduced the concept of "flow" to refer to occupational gender composition and occupation-crossing individuals. Following this line, Yamagata et al. (1997), when analyzing internal labor market (i.e. occupational gender segregation in organization), proposed two dimensions of occupational gender segregation: distribution dimension (gender composition) and flow dimension (occupational captivity). The former is the percentage of male and female in occupation, while the latter is the degree of occupational closure, meaning in a certain period, regardless of the gender composition in one occupation, individual can not move from one position inside the occupation to another or more from other occupations into this occupation, or vice versa. In other words, occupational 
captivity refers to the degree of entering into or exiting from a certain occupation. Therefore, both gender composition and occupational captivity dimensions can be used to examine occupational gender segregation in organization.

However, Wang (1993), while researching occupational gender segregation in Taiwan, found that occupational gender segregation has a close connection with educational degree, not exactly equal to occupational gender discrimination. This study also finds that there are two direct components of gender composition features and occupational captivity degree, one is gender discrimination, and the other is the lack of occupational qualification. Accordingly, occupational gender segregation can be divided into gender discrimination and lacking of occupational qualification. In this paper, occupational gender segregation refers to the former one.

\subsection{Glass ceiling}

The concept of glass ceiling, as an important indicator of gender discrimination, was coined in 1986 as a result of a three-year study, which reached a conclusion that glass ceiling is a serious obstacle for the progress of female and that some behaviors are unacceptable to female, while acceptable for male (Inman, 1998). Inman (1998) argued that glass ceiling is an invisible obstacle of preventing female in middle management level from being promoted to top management level. Wright and Baxter (2000) proposed that glass ceiling mainly exists in top management level, that is, glass ceiling means that the female face more disadvantages when they are promoted from lower managerial levels to top ones rather than among low managerial levels. As Powel and Butterfield (1994) and Kete et al. (2002) pointed out, glass ceiling is an invisible obstacle based on gender, irrelevant with job situations, which is faced by female who are going to be promoted to top managerial levels in an organization. Yamagata et al. (1997) pointed out that the concept consists of two dimensions, namely internal glass ceiling of primary occupation (occupational dimension) and external glass ceiling of primary occupation (organizational dimension). Based on their empirical study on second-hand data, Groot and Van den Brink (1996) found that female employees have less access to jobs with great promotion potentials. Even if female employees get such kind of jobs, they do not enjoy equal promotion opportunities as their male colleagues. The reason responsible for such phenomenon is that male and female are being treated differently based on their genders rather than individual's capabilities relevant with jobs.

As a conclusion, glass ceiling consists of two parts, namely in-occupational glass ceiling, the obstacle when female employees are promoted to top level in the same occupation in an organization, and out-occupational glass ceiling, the obstacle when female employees are promoted to top level crossing occupations 
in an organization.

\subsection{Salary gender discrimination}

Salary gender discrimination has the most direct impact on female's economic status in society. There has been a large amount of previous research focusing on salary gender discrimination. In 1986, Cain reviewed literature on salary gender discrimination and found that most studies divide the salary differences between male and female into two parts: one is legal one, which reflects employee's productivity differences; the other is illegal one, which is based on gender discrimination. OFCCP ${ }^{1}$ defines the salary discrimination as different treatment to individuals with similar skills and qualifications in job and responsible hierarchy. And gender salary discrimination refers to that female employees receive less salary than their male peers as a result of organization custom or enterprise policy, even if these female employees do the same job, have the same educational background and experience as their male peers (Alkadry, 2006).

Besides, Zhang (2004) summarized three forms of salary gender discrimination: (1) unequal pay for equal work, indicating that female and male are differently paid even if they have the same productivity; (2) occupation and position discrimination, indicating that sometimes, employers intently distribute positions with lower salary or responsibility to female employees who have the same educational level and productivity as male employees; (3) pre-market discrimination, indicating that female employees tend to have lower job expectation because of the lower reward for the female labor's human capital or the unequal treatment in training and promotion. Consequently, they reduce their investment in human capital before entering into the labor market, which in turn decrease their productivity and income. Out of these three forms, the second one belongs to occupational gender discrimination. Since the pre-market discrimination exists before female employees' entering into the labor market, it is not included in the research scope of this paper. Therefore, this study proposes that salary gender discrimination mainly represents unequal pay for equal work. Milgrom (2001) pointed out that unequal pay for equal work lies in two factors: one is unequal pay for equal work in occupation, meaning that female employees receive lower reward than male colleagues in a given occupation, the other is value discrimination, meaning that skill requirements and other factors relevant with salary being equal, employers offer different rewards to female-dominated jobs and male-dominated jobs.

Based on the above discussion, a theoretical model of manifestation of gender discrimination in HRD is developed, as shown in Fig. 1.

${ }^{1}$ OFCCP: Office of Federal Contract Compliance Programs. 


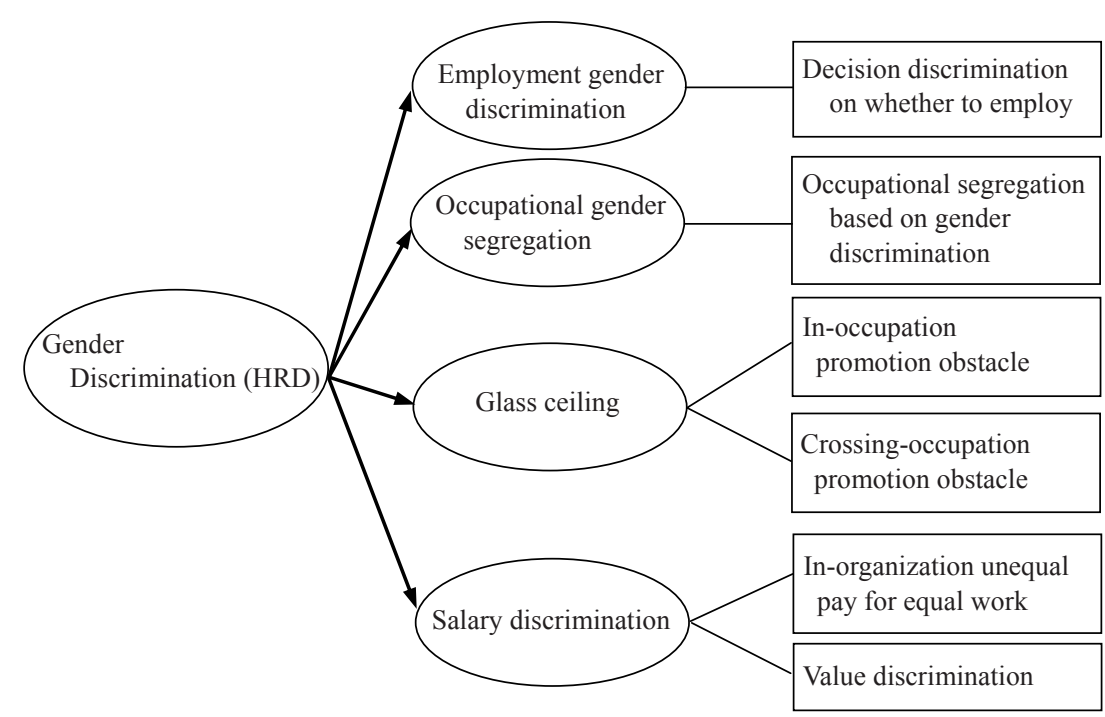

Fig. 1 Theoretical model of manifestation of gender discrimination in HRD

\section{Research method}

As above, few extant studies have investigated directly the manifestation of gender discrimination in HRD. To fill this research gap, we believe that first-hand scenarios of gender discrimination must be acquired from field study of enterprise and the results obtained from these scenarios can be used to shed light on these manifestations. Besides, compared with other investigation methods, interview can acquire abundant data and is beneficial to the attainment and comprehension of some new and deep information, which is favorable to future investigation. Furthermore, the interview is conducive to the building of a harmonious relationship between interviewees and interviewers which improves the validity and reliability of results (Wang, 1998; Yuan, 1997). Therefore, this study adopts semi-structured in-depth interview to get scenarios of manifestation of gender discrimination in HRD, and then educe manifestation of gender discrimination in HRD by using content analysis.

\subsection{Interview design}

Several relevant questions are designed for the research issue "manifestation of gender discrimination in HRD", For instance, "do you think there's gender discrimination to female in the process of HRD?" "If so, what will the manifestation be" or "can you for example", etc. These questions were used as 
the main clue in our interview. Specific interview process was as follows: Firstly, we explained the definition of HRD to the interviewees and then discussed with them properly. The interview generally lasted for 3 hours. In the interview, sometimes, we provided paper and pen to the interviewees and asked them to write down the scenarios of gender discrimination. After the interview, we recorded information we obtained from interview into word files. Through the in-depth interview on manifestation of gender discrimination in HRD, we acquired accurate first-hand scenarios, which become a favorable basis for the analysis on manifestation of gender discrimination in HRD.

\subsection{Participants}

60 employees from 55 enterprises, including 15 top managers, 30 middle-level managers and 15 first-line managers' employees participated in our interview. 25 were male and 35 were female. Among the 55 enterprises, 31 were private enterprises, 15 state-owned ones, and 9 foreign or joint enterprises. As for enterprise size, two thirds were middle or large-scale enterprises and one thirds small enterprises. The 94 scenarios given by participants are presented in Table 1.

Table 1 Specific origin for scenarios of gender discrimination in HRD

\begin{tabular}{|c|c|c|c|c|c|c|c|c|c|}
\hline Enterprise nature & \multicolumn{3}{|c|}{ SOE } & \multicolumn{3}{|c|}{$\mathrm{PE}$} & \multicolumn{3}{|c|}{ FFE } \\
\hline Position & $\mathrm{T}$ & $\mathrm{M}$ & $\mathrm{L}$ & $\mathrm{T}$ & $\mathrm{M}$ & $\mathrm{L}$ & $\mathrm{T}$ & $\mathrm{M}$ & $\mathrm{L}$ \\
\hline Numbers of scenarios & 7 & 14 & 6 & 12 & 23 & 18 & 2 & 7 & 5 \\
\hline Percentage & $7.4 \%$ & $14.9 \%$ & $6.4 \%$ & $12.8 \%$ & $24.5 \%$ & \begin{tabular}{l|l|}
6 & $19.1 \%$ \\
\end{tabular} & $2.1 \%$ & $7.4 \%$ & $5.3 \%$ \\
\hline Gender & \multicolumn{2}{|c|}{ Male } & Female & \multicolumn{2}{|c|}{ Male } & Female & \multicolumn{2}{|c|}{ Male } & Female \\
\hline Numbers of scenarios & \multicolumn{2}{|c|}{12} & 15 & \multicolumn{2}{|c|}{21} & 32 & \multicolumn{2}{|l|}{4} & 10 \\
\hline percentage & \multicolumn{2}{|c|}{$12.8 \%$} & $16.0 \%$ & \multicolumn{2}{|c|}{$22.3 \%$} & $34.0 \%$ & $4.3 \%$ & & $10.6 \%$ \\
\hline
\end{tabular}

Note: In the "enterprise nature" line, $\mathrm{SOE}=$ state-owned enterprises; $\mathrm{PE}=$ private enterprises; $\mathrm{FFE}=$ foreign (joint) funded enterprises. In the "position" line, $\mathrm{T}=$ top managers; $\mathrm{M}=$ middle-level manager; $\mathrm{L}=$ low-level managers or employees. The same in tables below.

\subsection{Analysis of interview data}

\subsubsection{Method}

Content analysis is used in this study due to the following reasons: First, it is an extremely important qualitative research method on the basis of quantitative analysis which has recently been emphasized and applied to various fields in social science research; second, it is a standardized method to distill content in literature and reflect massive literature data in an ordered and quantified way. Therefore, content analysis method can reduce subjectivity and orientation in an interview (Chen, 2001). The quantitative semantic method in content analysis 
was used to analyze the 94 scenarios of gender discrimination. Each scenario was used as the smallest analysis unit. Below are examples of three different scenarios.

Scenario 1: Once there were two candidates for a managerial position, one is a male employee, who always asks his subordinates to finish his jobs for him; the other is a female, industrious, capable and sophisticated. However, the Japanese minister finally promoted the male as section chief. We were all surprised and angry.

Scenario 2: I know a lady from the marketing department. Although she is one of the best employees in her department and has achieved excellent job performance, she has never been promoted. Her current general manager believed that as a female, she must be narrow-minded and therefore is not suitable for any leading positions in the department.

Scenario 3: Capable female employees in my unit are at disadvantageous positions in promotion after fertility, which finally influences negatively their career development. Our leaders believe that having a baby does not only influence these female employees' jobs, but also negatively changes their way of thinking. Therefore, female employees with children are not suitable for creative jobs any more.

According to the coding table constructed for manifestation of gender discrimination in HRD, one paragraph was used as an analysis unit. We captured the overall relevant information and made detailed coding. As required by the content analysis, this study invited two experts as coders, one was associate professor of HRM and the other holds a master degree in HRM. ${ }^{2}$

\subsubsection{Development of coding table}

This study develops a coding table for manifestation of gender discrimination in HRD based on the analysis of previous literature. According to the concept of enterprise HRD, several stages of HRD can be clarified, including stages of recruitment, job arrangement, training, salary management and performance evaluation. Associated with the theoretical model for manifestation of gender discrimination developed above and the research conclusion got by interviewers, this study specifies the manifestation of gender discrimination in HRD into employment gender discrimination, occupational gender discrimination, glass ceiling and salary gender discrimination; Besides, other situations are added in order to obtain other possible manifestations. For example, some scholars such as Long (1975), Liu et al. (2000), argued that the manifestation of gender discrimination vary greatly with different enterprise types and background.

${ }^{2}$ The two coders are also the researchers of this program. 
Therefore, the background of interviewees is also included in the coding table as shown below, enterprise nature (state-owned enterprise, private enterprise, or foreign or joint funded enterprise), position (top manager, middle-level manager, low-level manager or common employees) and gender (male, female). Specific coding table is presented in Table 2.

Table 2 Coding table of manifestation of gender discrimination in HRD

\begin{tabular}{|c|c|c|c|c|c|c|c|c|c|c|c|c|}
\hline & & \multicolumn{5}{|c|}{ Stages of HRD } & \multicolumn{6}{|c|}{$\begin{array}{l}\text { manifestation of gender } \\
\text { discrimination }\end{array}$} \\
\hline & & Recruiment & $\begin{array}{l}\text { Job } \\
\text { arrangement }\end{array}$ & Training & $\begin{array}{l}\text { Salary } \\
\text { management }\end{array}$ & $\begin{array}{r}\text { Performance } \\
\text { evaluation }\end{array}$ & E & $\mathrm{O}$ & G & S & $\mathrm{O} 1$ & $\mathrm{O} 2$ \\
\hline \multirow{3}{*}{$\begin{array}{c}\text { Enterprise } \\
\text { nature }\end{array}$} & SOE & & & & & & & & & & & \\
\hline & $\mathrm{PE}$ & & & & & & & & & & & \\
\hline & FFE & & & & & & & & & & & \\
\hline \multirow{3}{*}{ Position } & $\mathrm{S}$ & & & & & & & & & & & \\
\hline & M & & & & & & & & & & & \\
\hline & $\mathrm{L}$ & & & & & & & & & & & \\
\hline \multirow{2}{*}{ Gender } & $\mathrm{M}$ & & & & & & & & & & & \\
\hline & $\mathrm{F}$ & & & & & & & & & & & \\
\hline
\end{tabular}

Note: In the gender line, $\mathrm{M}=$ male; $\mathrm{F}=$ female; in the column of "manifestation of gender discrimination" $\mathrm{E}, \mathrm{O}, \mathrm{G}, \mathrm{S}, \mathrm{O} 1$, and $\mathrm{O} 2$ stand for the "employment gender discrimination", "occupational gender segregation", "glass ceiling, gender salary discrimination", "other situation 1", and "other situation 2", respectively.

As indicated in the second part concerning the theoretical model for manifestation of gender discrimination in HRD, employment gender discrimination is the gender discrimination on the decision of whether to employ an applicant or not; occupational gender segregation is the occupational segregation based on gender; glass ceiling includes glass ceiling both based on in-occupation promotion and crossing-occupation promotion; and salary gender discrimination refers to unequal pay for equal work and value discrimination. The content analysis is the process to analyze whether the scenarios of gender discrimination acquired reflect such manifestations.

\subsubsection{Result of content analysis}

\subsubsection{Reliability and validity testing}

As for the reliability of content analysis, this study adopts the most commonly used method, which is the method based on the degree of consistency between coders. Due to the explicit background of interviewees, the consistency coefficients of coders all equal 1 (due to space limitation, no extra table on this is presented below). Consistency coefficients of stages of HRD all equal 1, while 
consistency coefficients of manifestations of gender discrimination are all above 0.90 (as show in Table 3), indicating an excellent reliability.

Table 3 Results of reliability analysis of manifestation of gender discrimination in HRD

\begin{tabular}{clc}
\hline \multicolumn{1}{c}{ Category } & \multicolumn{1}{c}{ Item } & Consistency coefficient \\
\hline Stages of HRD & Recruitment & 1.00 \\
& Job arrangement & 1.00 \\
& Training & 1.00 \\
& Salary management & 1.00 \\
& Promotion evaluation & 1.00 \\
Manifestation & Employment gender discrimination & 0.92 \\
of gender & Occupational gender Segregation & 0.92 \\
discrimination & Glass ceiling & 0.94 \\
& Salary gender discrimination & 1.00 \\
& Other 1 (work overtime and less development & 1.00 \\
& $\quad$ opportunities ) & 1.00 \\
\hline
\end{tabular}

As for the validity of content analysis, content validity testing (CVR) method is adopted. First, this study has sound theoretical and practical basis. Construction of the coding table is strictly based on previous studies and relevant concept definition. In addition, ten professionals and researchers in this field were invited to make evaluation on the content validity. The resulting of the CVR equals $1 .^{3}$ Then, the process of coding strictly keeps to coding procedure: coders were trained carefully again, in spite of their previous experience in the field and although pilot coding was conducted before formal coding. All these help to improve the final content validity.

3.3.3.2 Statistical analysis of coding result of manifestation of gender discrimination in HRD

Three perspectives are adopted in this study to analyze manifestation of gender discrimination in HRD: First, overall perspective. In exploring the manifestations and characteristics of gender discrimination at work, we do not consider variables of enterprise background and stages of HRD; second, variables of individual and enterprise background are included in the analysis; finally, stages of HRD are included into the analysis of manifestation and characteristics of gender discrimination.

${ }^{3}$ According to Professor Wang Zhongming, CVR is a common index to evaluate content validity. For more details, please refer to Wang Zhongming (1998). Psychology Research Methods. Beijing: People's Educational Press. 140. 
Table 4 Coding results of manifestation of gender discrimination in HRD from the overall perspective

\begin{tabular}{lcc}
\hline Manifestation of gender discrimination & Frequency & Percentage of frequency \\
\hline Employment gender discrimination & 46 & $24.5 \%$ \\
Occupational gender segregation & 73 & $38.8 \%$ \\
Glass ceiling & 37 & $19.7 \%$ \\
Salary gender discrimination & 22 & $11.7 \%$ \\
Other 1 (task opportunity discrimination) & 6 & $3.2 \%$ \\
Other 2 (training discrimination) & 4 & $2.1 \%$ \\
\hline
\end{tabular}

It can be seen from Table 4 that without considering the enterprise background and stages of HRD, occupational segregation based on gender discrimination has the highest frequency (73 cases, accounting for 38.8\%); second highest with employment discrimination, accounting for $24.5 \%$. Taken together, these two manifestations have a frequency of 119 , accounting for $63.3 \%$. The frequencies of glass ceiling and salary gender discrimination account for $19.7 \%$ and $11.7 \%$, respectively. In addition to these manifestations, there are two more manifestations being reflected in the study, namely task opportunity discrimination, that is, female employees with equal position and qualifications as their male peers receive less mission opportunities (3.2\%) and training opportunities $(2.1 \%)$.

The results of content analysis on manifestation of gender discrimination taking into consideration of variables of individual position and gender in HRD are presented in Table 5 and 6 , respectively.

Table 5 Results of content analysis on manifestation of gender discrimination related to individual position in HRD

\begin{tabular}{|c|c|c|c|c|c|c|}
\hline & $\begin{array}{l}\text { Employment } \\
\text { discrimination } \\
\text { frequency } \\
\text { percentage }\end{array}$ & $\begin{array}{l}\text { Occupational } \\
\text { gender } \\
\text { segregation } \\
\text { frequency } \\
\text { percentage } \\
\end{array}$ & $\begin{array}{l}\text { Glass ceiling } \\
\text { frequency } \\
\text { percentage }\end{array}$ & $\begin{array}{l}\text { Salary } \\
\text { discrimination } \\
\text { frequency } \\
\text { percentage }\end{array}$ & $\begin{array}{l}\text { Task } \\
\text { discrimination } \\
\text { frequency } \\
\text { percentage }\end{array}$ & $\begin{array}{l}\text { Training } \\
\text { discrimination } \\
\text { frequency } \\
\text { percentage }\end{array}$ \\
\hline \multirow[t]{2}{*}{ Top } & 3 & 18 & 11 & 6 & 0 & 2 \\
\hline & $6.5 \%$ & $24.7 \%$ & $29.7 \%$ & $27.3 \%$ & $0 \%$ & $50 \%$ \\
\hline \multirow[t]{2}{*}{ Middle } & 17 & 37 & 22 & 10 & 2 & 2 \\
\hline & $37.0 \%$ & $50.7 \%$ & $59.5 \%$ & $45.5 \%$ & $33.3 \%$ & $50 \%$ \\
\hline \multirow[t]{2}{*}{ lower } & 26 & 18 & 4 & 6 & 4 & 0 \\
\hline & $56.5 \%$ & $24.7 \%$ & $10.8 \%$ & $27.3 \%$ & $66.7 \%$ & 0 \\
\hline Mop/middle & 3.238 & 0.008 & 0.021 & 0.225 & & \\
\hline $\begin{array}{l}\text { Chi-Square } \\
\text { value }\end{array}$ & 0.072 & 0.930 & 0.884 & 0.635 & & \\
\hline \multicolumn{7}{|l|}{ Significance } \\
\hline Middle/lower & $10.949^{* * * *}$ & 1.805 & $7.828^{* *}$ & 0.037 & & \\
\hline $\begin{array}{l}\text { Chi-Square } \\
\text { value }\end{array}$ & 0.001 & 0.179 & 0.005 & 0.847 & & \\
\hline Significance & & & & & & \\
\hline
\end{tabular}




\begin{tabular}{|c|c|c|c|c|c|c|}
\hline & $\begin{array}{l}\text { Employment } \\
\text { discrimination } \\
\text { frequency } \\
\text { percentage }\end{array}$ & $\begin{array}{l}\text { Occupational } \\
\text { gender } \\
\text { segregation } \\
\text { frequency } \\
\text { percentage }\end{array}$ & $\begin{array}{l}\text { Glass ceiling } \\
\text { frequency } \\
\text { percenta } \\
\text { ge }\end{array}$ & $\begin{array}{l}\text { Salary } \\
\text { discrimination } \\
\text { frequency } \\
\text { percentage }\end{array}$ & $\begin{array}{l}\text { Task } \\
\text { discrimination } \\
\text { frequency } \\
\text { percentage }\end{array}$ & $\begin{array}{l}\text { Training } \\
\text { discrimination } \\
\text { frequency } \\
\text { percentage }\end{array}$ \\
\hline Top/lower & $16.802^{* * * *}$ & 1.478 & $7.112^{* *}$ & 0.358 & & \\
\hline $\begin{array}{l}\text { Chi-Square } \\
\text { value } \\
\text { Significance }\end{array}$ & 0.000 & 0.224 & 0.008 & 0.549 & & \\
\hline
\end{tabular}

It is indicated by frequency analysis in Table 5 that among the four manifestations, top and middle-level managers perceive occupational gender segregation and glass ceiling with highest frequency, while low-level managers perceive more employment gender discrimination and occupational gender segregation, with the frequencies of 26 and 18, respectively. Besides, the results of Chi-square show that there are no significant differences between top and middle managers in employment gender discrimination, occupational gender segregation, glass ceiling and salary gender discrimination, but there are significant differences both between middle and low-level managers and between top and low-level managers in employment gender discrimination and glass ceiling, as indicated by significant chi-square values at 0.001 and 0.01 levels. However, both occupational gender segregation and salary gender discrimination are not significant. These results indicate that compared with top and middle managers, low-level managers can perceive more employment gender discrimination and less glass ceiling.

Table 6 Results of content analysis on manifestation of gender discrimination related to gender in HRD

\begin{tabular}{lcccccc}
\hline & $\begin{array}{c}\text { Employment } \\
\text { discrimination } \\
\text { frequency } \\
\text { percentage }\end{array}$ & $\begin{array}{l}\text { Occupational } \\
\text { gender } \\
\text { segregation } \\
\text { frequency } \\
\text { percentage }\end{array}$ & $\begin{array}{l}\text { Glass ceiling } \\
\text { frequency } \\
\text { percentage }\end{array}$ & $\begin{array}{l}\text { Salary } \\
\text { nation } \\
\text { frequency }\end{array}$ & $\begin{array}{l}\text { Task } \\
\text { discrimi- } \\
\text { nation } \\
\text { frequency } \\
\text { percentage }\end{array}$ & $\begin{array}{l}\text { Training } \\
\text { discrimi- } \\
\text { nation } \\
\text { frequency } \\
\text { percentage }\end{array}$ \\
\hline Male & 19 & 35 & 12 & 6 & 2 & 2 \\
Female & $41.3 \%$ & $47.9 \%$ & $32.4 \%$ & $27.3 \%$ & $33.3 \%$ & $50 \%$ \\
\hline Chi-Square & 27 & 38 & 25 & 16 & 4 & 2 \\
value & $58.7 \%$ & $52.1 \%$ & $67.6 \%$ & $72.7 \%$ & $66.7 \%$ & $50 \%$ \\
Significance & 0.096 & 3.684 & 0.927 & 1.526 & & \\
\hline
\end{tabular}

As shown in Table 6, both male and female can perceive most occupational 
gender segregation, followed by employment gender discrimination, and lest salary gender discrimination. Besides, the result of chi-square shows that all the four manifestations of gender discrimination in HRD are not significantly different between male and female. That is, there is no significant difference between male and female on the perception of employment gender discrimination, occupational gender segregation, glass ceiling and salary gender discrimination

Based on the above analysis, there are differences between different positions on the manifestations of employment gender discrimination and glass ceiling. Therefore, we exclude position feature in the content analysis including variable of enterprise nature. Results of content analysis are presented in Table 7 on manifestation of gender discrimination in HRD based on enterprise nature.

Table 7 Results of content analysis on manifestation of gender discrimination related to different enterprise natures in HRD

\begin{tabular}{|c|c|c|c|c|c|c|c|}
\hline & & $\begin{array}{l}\text { Employment } \\
\text { discrimination } \\
\text { frequency } \\
\text { percentage }\end{array}$ & $\begin{array}{l}\text { Occupational } \\
\text { gender } \\
\text { segregation } \\
\text { frequency } \\
\text { percentage }\end{array}$ & $\begin{array}{c}\text { Glass ceiling } \\
\text { frequency } \\
\text { percentage }\end{array}$ & $\begin{array}{l}\text { Salary } \\
\text { discrimination } \\
\text { frequency } \\
\text { percentage }\end{array}$ & $\begin{array}{l}\text { Task } \\
\text { discrimination } \\
\text { frequency } \\
\text { percentage }\end{array}$ & $\begin{array}{l}\text { Training } \\
\text { discrimination } \\
\text { frequency } \\
\text { percentage }\end{array}$ \\
\hline \multirow[t]{6}{*}{ Top } & SOE & 1 & 6 & 5 & 0 & 0 & 2 \\
\hline & & $33.3 \%$ & $33.3 \%$ & $45.5 \%$ & $0 \%$ & $0 \%$ & $50 \%$ \\
\hline & PE & 2 & 10 & 4 & 6 & 0 & 2 \\
\hline & & $66.7 \%$ & $55.6 \%$ & $36.4 \%$ & $100 \%$ & $0 \%$ & $50 \%$ \\
\hline & FFE & 0 & 2 & 2 & 0 & 0 & 0 \\
\hline & & $0 \%$ & $11.1 \%$ & $18.2 \%$ & $0 \%$ & $0 \%$ & $0 \%$ \\
\hline \multirow[t]{6}{*}{ Middle } & SOE & 6 & 14 & 4 & 4 & 0 & 0 \\
\hline & & $35.3 \%$ & $37.8 \%$ & $18.2 \%$ & $40.0 \%$ & $0 \%$ & $0 \%$ \\
\hline & PE & 9 & 17 & 12 & 6 & 2 & 0 \\
\hline & & $52.9 \%$ & $45.9 \%$ & $54.5 \%$ & $60.0 \%$ & $100 \%$ & $0 \%$ \\
\hline & FFE & 2 & 6 & 6 & 0 & 0 & 0 \\
\hline & & $11.8 \%$ & $16.2 \%$ & $27.3 \%$ & $0 \%$ & $0 \%$ & $0 \%$ \\
\hline \multirow[t]{6}{*}{ Lower } & SOE & 8 & 2 & 0 & 0 & 2 & 0 \\
\hline & & $30.8 \%$ & $11.1 \%$ & $0 \%$ & $0 \%$ & $50 \%$ & $0 \%$ \\
\hline & PE & 18 & 8 & 2 & 6 & 2 & 0 \\
\hline & & $69.2 \%$ & $44.4 \%$ & $50.0 \%$ & $100 \%$ & $50 \%$ & $0 \%$ \\
\hline & FFE & 0 & 8 & 2 & 0 & 0 & 0 \\
\hline & & $0 \%$ & $44.4 \%$ & $50.0 \%$ & $0 \%$ & $0 \%$ & $0 \%$ \\
\hline \multirow[t]{2}{*}{$\mathrm{SOE} / \mathrm{PE}$} & $\mathrm{T}$ & 0.017 & 0.005 & 1.775 & $4.156^{*}$ & & \\
\hline & & 0.896 & 0.943 & 0.183 & 0.041 & & \\
\hline \multirow{4}{*}{$\begin{array}{l}\text { Chi-Square } \\
\text { value } \\
\text { significance }\end{array}$} & M & 0.037 & 1.216 & 1.430 & 0.023 & & \\
\hline & & 0.847 & 0.270 & 0.232 & 0.880 & & \\
\hline & $\mathrm{L}$ & 1.007 & 0.168 & 0.696 & 2.286 & & \\
\hline & & 0.316 & 0.682 & 0.404 & 0.131 & & \\
\hline
\end{tabular}




\begin{tabular}{|c|c|c|c|c|c|c|c|}
\hline & & $\begin{array}{l}\text { Employment } \\
\text { discrimination } \\
\text { frequency } \\
\text { percentage }\end{array}$ & $\begin{array}{l}\text { Occupational } \\
\text { gender } \\
\text { segregation } \\
\text { frequency } \\
\text { percentage }\end{array}$ & $\begin{array}{c}\text { Glass ceiling } \\
\text { frequency } \\
\text { percentage }\end{array}$ & $\begin{array}{l}\text { Salary } \\
\text { discrimination } \\
\text { frequency } \\
\text { percentage }\end{array}$ & $\begin{array}{l}\text { Task } \\
\text { discrimination } \\
\text { frequency } \\
\text { percentage }\end{array}$ & $\begin{array}{l}\text { Training } \\
\text { discrimination } \\
\text { frequency } \\
\text { percentage }\end{array}$ \\
\hline \multirow[t]{2}{*}{$\mathrm{PE} / \mathrm{EEE}$} & $\mathrm{T}$ & 0.359 & 0.097 & 2.263 & 1.273 & & \\
\hline & & 0.549 & 0.755 & 0.133 & 0.259 & & \\
\hline \multirow{4}{*}{$\begin{array}{l}\text { Chi-Square } \\
\text { value } \\
\text { significance }\end{array}$} & M & 0.200 & 0.158 & 1.437 & 2.029 & & \\
\hline & & 0.655 & 0.691 & 0.231 & 0.154 & & \\
\hline & $\mathrm{L}$ & $8.241^{* * *}$ & $11.517^{* * * *}$ & 2.057 & 1.917 & & \\
\hline & & 0.004 & 0.001 & 0.152 & 0.166 & & \\
\hline \multirow[t]{2}{*}{ SOE/EFE } & $\mathrm{T}$ & 0.303 & 0.064 & 0.267 & - & & \\
\hline & & 0.582 & 0.800 & 0.605 & - & & \\
\hline \multirow{4}{*}{$\begin{array}{l}\text { Chi-Square } \\
\text { value } \\
\text { significance }\end{array}$} & M & 0.309 & 0.191 & $4.200^{*}$ & 2.211 & & \\
\hline & & 0.578 & 0.662 & 0.040 & 0.137 & & \\
\hline & $\mathrm{L}$ & $10.476^{* * *}$ & $8.824^{* *}$ & 2.640 & - & & \\
\hline & & 0.001 & 0.003 & 0.104 & - & & \\
\hline
\end{tabular}

As shown in Table 7, top and middle managers have the highest frequency of occupational gender in both private enterprise and foreign (joint) funded enterprises. Specifically, the frequencies of glass ceiling (2) and occupational gender segregation (6) are highest in foreign (joint) funded enterprises. Besides, low-level managers have the highest frequencies of employment gender discrimination in state-owned enterprises (8) and private enterprises (18), while they have the highest frequency of occupational gender segregation in foreign funded enterprise (8). Except private enterprise, managers at all levels in the other two types of enterprises perceive least salary gender discrimination. Chi-square shows that there are no significant differences in employment gender discrimination, occupational gender segregation and glass ceiling among managers at all levels in both state-owned and private enterprises.

However, as for salary gender discrimination, there is significant difference (significant at 0.05 level) between top managers in state-owned and private enterprises. Associated with frequency analysis, we can find that more salary discrimination is perceived among top managers in private enterprises than that of state-owned enterprises. Furthermore, it is shown by chi-square analysis that there is no significant difference in terms of the four manifestations of gender discrimination among top and middle-level managers between private enterprise and foreign (joint) funded enterprises. However, there are significant differences in employment gender discrimination (significant at 0.01 level) and occupational gender segregation (significant at 0.001 level) perceived by low-level managers in these two types of enterprises, which have significant difference. As shown by 
the frequency analysis, it is clear that low-level managers in private enterprise can perceive more employment gender discrimination than their counterparts in foreign (joint) funded enterprises, while low-level managers in foreign (joint) funded enterprises perceive more occupational gender segregation (though with same frequencies, the percentages are greatly different. The percentage of perceived occupational gender segregation among low-level managers in foreign (joint) funded and private enterprises are $80 \%$ and $22.2 \%$, respectively). Finally, it is indicated by chi-square analysis that there is significant difference (significant at 0.05 level) in glass ceiling perceived by middle-level managers in state-owned enterprise and foreign (joint) funded enterprises.

Associated with frequency analysis, it can be found that middle-level managers in foreign (joint) funded capital enterprises perceive more glass ceiling than their counterparts in state-owned enterprises. There are significant differences in employment gender discrimination and occupational gender segregation perceived by low-level managers in state-owned and foreign (joint) funded enterprises. Their chi-square values are significant at 0.001 and 0.01 levels, respectively. Associated with frequency analysis, it is clear that low-level managers in state-owned enterprise perceive more employment gender discrimination and less occupational gender segregation than their counterparts in foreign (joint) funded enterprises.

Coding results of manifestation of gender discrimination based on stages of HRD are presented in Table 8.

Table 8 Results of content analysis on manifestation of gender discrimination related to different stages of HRD

\begin{tabular}{|c|c|c|c|c|c|c|}
\hline & $\begin{array}{l}\text { Employment } \\
\text { discrimination } \\
\text { frequency } \\
\text { (percentage) }\end{array}$ & $\begin{array}{l}\text { Occupational } \\
\text { gender } \\
\text { segregation } \\
\text { frequency } \\
\text { (percentage) }\end{array}$ & $\begin{array}{l}\text { glass ceiling } \\
\text { frequency } \\
\text { (percentage) }\end{array}$ & $\begin{array}{l}\text { Salary } \\
\text { discrimination } \\
\text { frequency } \\
\text { (percentage) }\end{array}$ & $\begin{array}{l}\text { Task } \\
\text { discrimination } \\
\text { frequency } \\
\text { (percentage) }\end{array}$ & $\begin{array}{l}\text { Training } \\
\text { discrimination } \\
\text { frequency } \\
\text { (percentage) }\end{array}$ \\
\hline Recruitment & $43(22.9 \%)$ & $7(3.7 \%)$ & 0 & 0 & 0 & 0 \\
\hline $\begin{array}{l}\text { Job } \\
\text { arrangement }\end{array}$ & $3(1.6 \%)$ & $64(34.0 \%)$ & $37(19.7 \%)$ & $2(1.1 \%)$ & $6(3.2 \%)$ & 0 \\
\hline Training & 0 & 0 & 0 & 0 & 0 & $4(2.1 \%)$ \\
\hline $\begin{array}{l}\text { Salary } \\
\text { management }\end{array}$ & 0 & 0 & 0 & $20(10.6 \%)$ & 0 & 0 \\
\hline $\begin{array}{r}\text { Performance } \\
\text { evaluation }\end{array}$ & 0 & $2(1.1 \%)$ & 0 & 0 & 0 & 0 \\
\hline
\end{tabular}

As shown in Table 8, specifically, employment discrimination mainly exists at the employment stage (frequency $=43$ ); occupational gender segregation and glass ceiling job in arrangement stage (frequency $=64$ and 37, respectively); training 
discrimination in training stage (frequency $=4$ ); and salary discrimination in salary management stage (frequency $=20$ ). In addition, we can also find out that gender discrimination has the highest frequency (112) at the job arrangement stage, accounting for 59.6\%. By comparison, the performance evaluation stage has the least frequency (2).

\section{Discussion and conclusions}

In this study, a theoretical model for manifestation of gender discrimination is developed based on previous literature. First-hand scenarios of enterprise gender discrimination are acquired through in-depth interviews. Results of structural content analysis on the interview data primarily confirm the manifestations and characteristics of gender discrimination in HRD.

The analyzing results based on manifestation of gender discrimination in HRD are twofold. First, in general, the gender discrimination in enterprise HRD manifests in gender segregation, employment gender discrimination, glass ceiling and salary gender discrimination, which is based on gender discrimination. Among these four forms, the phenomenon of occupational gender segregation and employment gender discrimination are most common. Such results are consistent with the argument of Epstein (1992), who proposed that compared with promotion and dismissal discrimination, enterprises prefer to take the risk of being charged of employment discrimination. The research conducted by Zhu et al. (2003) also confirmed this argument from a different perspective. They found that as a whole, the numbers of occupations rejecting female are more than that of rejecting male. In addition, female-dominated occupations do not strongly reject male while male-dominated occupations tend to greatly reject female. Second, there are two additional manifestations of gender discrimination in HRD: task discrimination and training discrimination, meaning that female employees are at disadvantageous positions in terms of task arrangement and training opportunity. However, we regard task and training discrimination as manifestations of glass ceiling in this study because both of them make female employees have less access to higher positions. In other words, glass ceiling should be a process which manifests both as the result of promotion and in the process of promotion. The definition given by Daily et al. (1999) also expressed such a view. They argued that glass ceiling is a metaphor for obstacles preventing female from leading a certain organizational hierarchy. Such a definition highlights the process of "leading to".

The analyzing results of manifestation of gender discrimination in HRD based on individual and enterprise background show that firstly, among the four 
manifestations of gender discrimination, occupational gender segregation and glass ceiling are more frequently perceived by top and middle-level managers, while employment gender discrimination and occupational gender segregation are more frequently perceived by general employees (or low-level managers). These findings indicate the universality of occupational gender segregation, which partially explains why occupational gender segregation has always been a hotspot in gender discrimination research. In addition, compared with top and middle-level managers, grassroots employees perceive more employment gender discrimination and less glass ceiling. The cause may be that having more experiences in promotion process, top and middle-level managers are more aware of the existence of glass ceiling in promotion, while the challenge faced by grassroots employees is whether they will be employed by a certain organization, so they are sensitive to gender discrimination issues in employment. Second, there is no significant difference between male and female in employment gender discrimination, occupational gender segregation, glass ceiling and salary gender discrimination. Third, general employees in foreign (joint) funded enterprise perceive more occupational gender segregation and less employment gender discrimination than employees in state-owned and private enterprises; besides, middle-level managers in foreign (joint) funded enterprise perceive more glass ceiling than their counterparts in state-owned enterprise; top managers in private enterprise perceive more salary gender discrimination than their counterparts in state-owned enterprises.

Our results show that, by compassion, occupational gender segregation and glass ceiling are more prominent in foreign (joint) funded enterprises, while salary gender discrimination is more prominent in private enterprises. As Liu et al. (2000) once pointed out that marketization leads to salary gap, the reason that there is serious salary gender discrimination in private enterprises may be that, compared with state-owned enterprises, private enterprise greatly emphasize marketization, cost saving and strong autonomy of salary system, which make them more "vulnerable" to salary gender discrimination. However, most foreign (joint) funded enterprises are under strict legal constraints on gender discrimination issues which lead to higher cost of gender discrimination. Therefore, discrimination in foreign (joint) funded enterprises seldom happens in forms of employment decision and salary payment (easy to be discovered by regulatory bodies), but in forms of gender discrimination, such as occupational gender segregation and glass ceiling which are more difficult to be traced by regulatory bodies and the public. Besides, the conclusion that salary gender discrimination is prominent in private enterprise is an extension to the empirical research conclusion made by Liu in 2000 who discovered, with a comparative study of gender salary differences in state-owned, collective and private sectors, 
that private sector has bigger gender salary gaps than that of state-owned sector and competitiveness of female employees is not as strong as male employees (due to the above-mentioned reason). This study, with acquirement and analysis of the gender discrimination scenarios, primarily ascertains that compared with state-owned enterprises, salary gender discrimination occurs more frequently in private enterprises.

Our analysis also shows that during the process of HRD, gender discrimination is most likely to occur at the job arrangement stage, second highest with the employment stage and least with the performance evaluation stage. Besides, employment discrimination is most likely to occur at the employment stage, occupational gender segregation and glass ceiling at the job arrangement stage, and salary discrimination at the salary management stage. All the above conclusions indicate that at different stages of HRD and HR practices, the degree of gender discrimination and specific manifestation vary, which set us wandering "what role does HR management practice play in organization". The settlement of the problem can lay a solid foundation to reduce and eliminate enterprise gender discrimination and provide theoretical guidance to develop the strategy to reduce and eliminate enterprise gender discrimination on the macro-level. It is emphasized by Reskin (2000) that most gender discriminations occur in people's normal cognition, but it can be activated or inhibited by organizational arrangement. Hence, if we try to get rid of gender discrimination in organization, we must first acknowledge that discriminations at work do exist and occur in HR practices in organization. However, the majority of recent studies on gender discrimination consider organization as neutral zone, placing organizational management practice out of research model (Ely and Padavic, 2007).Therefore, bringing HR management practice into gender discrimination analysis model has become an important direction in present gender discrimination research, which is illustrated by this study.

In conclusion, this study emphasizes the manifestation of gender discrimination in the process of HRD and our results support the theoretical assumption that manifestation of gender discrimination in HRD including employment gender discrimination, occupational segregation are based on gender discrimination, glass ceiling and salary gender discrimination. Our study lays a foundation for future research on gender discrimination in the process of HRD. Meanwhile, it represents an endeavor to bring gender discrimination research into the context of HR management. We believe that the placing of HR management practice into gender discrimination research model is a topic worth further analyzing and discussing.

Acknowledgements This paper is supported by the National Social Science Foundation of China (No. 06CJY011). The authors thank the anonymous reviewers for their valuable 
comments and suggestions.

\section{References}

Alkadry M G (2006). Unequal pay: The role of gender. Public Administration Review, 66(6): 888-898

Bellizzi A J, Hasty R W (2000). Does successful work experience mitigate weight and gender-based employment discrimination in face to face industrial selling? Journal of Business \& Industrial Marketing, 15(6): 384-398

Cain G G (1986). The economic analysis of labor market discrimination: A survey, In: Ashenfelter O and Layard R (eds.), Handbook of Labor Economics, 1: 693-785. New York: Elsevier Science Publishers

Daily C M, Certo S T, Dalton D R (1999). A decade of corporate female: Some progress in the boardroom, none in the executive suite. Strategic Management Journal, 20: 93-99

Ely R, Padavic I (2007). A feminist analysis of organizational research on sex differences. Academy of Management Review, 32(4): 1121-1143

Epstein R A (1992). Forbidden Grounds: The Case against Employment Discrimination Laws. Cambridge, MA: Harvard University Press

Groot W, Van den Brink H M (1996). Glass ceiling or dead ends: Job promotion of men and female compared. Economics Letters, 53: 221-226

Gutek B A, Cohen A G, Tsui A (1996). Reactions to perceived discrimination. Human Relations, 49: 791-813

Haberfeld Y (1992). Employment discrimination model: An organizational model. Academy of Management Journal, 35(1): 161-180

Heery E, Noon M (2001). A Dictionary of Human Resource Management, 160-161. New York: Oxford University Press

Inman P L (1998). Female' career development at the glass ceiling. New Directions for Adult and Continuing Education, 80: 35-42

Jacobs A J (1993). Theoretical and measurement issues in the study of sex segregation in the workplace: Research note. European Sociological Review, 9(3): 325-330

Kolbe R H, Burnett M S (1991). Content-analysis research: An examination of applications with directives for improving research reliability and objectivity. Journal of Consumer Research, 18(9): 243-250

Liu P W, Meng X, Zhang J S (2000). Sectorial gender wage differentials and discrimination in the transitional Chinese economy. Journal of Population Economics, 13: 331-352

Long J E (1975). Public-private sectoral differences in employment discrimination. Southern Economic Journal, 42(1): 89-96

Milgrom M M (2001). Equal pay for equal work? Evidence from Sweden and a comparison with Norway and the US. Scand J of Economics, 103(4): 559-583

Ngo H Y, Tang C, W Au (2002). Behavioral responses to employment discrimination: A study of Hongkong workers. International Journal of Human Resource Management, 13: 1206-1223

Petersen T, Togstad T (2006). Getting the offer: Sex discrimination in hiring. Research in Social Stratification and Mobility, 24: 239-257

Powell N G, Butterfield A D (1994). Investigating the "glass ceiling" phenomenon: An empirical study of actual promotions to top management. Academy of Management Journal, 
37(1): $68-86$

Reskin B F (2000). The proximate causes of employment discrimination. Contemporary Sociology, 29(2): 319-328

Wright E O, Baxter J (2000). The glass ceiling hypothesis: A reply to critics. Gender \& Society, 14(6): 814-821

Yamagata H, Yeh K S, Stewman S, Dodge H (1997). Sex segregation and glass ceilings: A comparative static model of female's career opportunities in the Federal Government over a quarter century. The American Journal of Sociology, 103(3): 566-632

蔡禾, 吴小平 (Cai He, Wu Xiaoping) (2002). 社会变迁与职业的性别不平等 (Social transition and occupational gender inequity). 管理世界, (9): 71-77

陈维军 (Chen Weijun) (2001). 文献计量法与内容分析法的比较研究 (Comparison between bolometric method and content analysis method). 情报科学, (8): 884-886

丁文 (Ding Wen) (1995). 关于妇女社会地位指标体系的理论探讨 (A study and assumption of female social status index system). 新华文摘, (8): 38-43

科特等 (Kete D A et al.) (2002). 玻璃天花板的影响 (Influence of glass ceiling). 国外社会科学, (4): 93-94

李新建, 赵瑞美 (Li Xinjian, Zhao Ruimei) (1999). 性别歧视与女性就业 (Sexual discrimination and female's employment). 妇女研究论从, (1): 4-9

马文峰 (Ma Wenfeng) (2000). 试析职业性别隔离 (Application of content analysis method in the social and scientific information science). 情报科学, (4): 346-349

王俊 (Wang Jun) (2004). 浅析职业性别隔离 (Simple analysis on professional sexism). 企业技 术开发, (12): 55-57

王重鸣 (Wang Zhongming) (1998). 心理学研究方法 (Psychology Research Methods), 168-169. 北京: 人民教育出版社

王雅芬 (Wang Yafen) (1993). 台湾地区职业结构性别差异与教育程度关联性之研究 (Study on the relevance between gender differences in occupational structure and educational degree in Taiwan, labor studies). 劳动研究, (113): 20-31

袁方 (Yuan Fang) (1997). 社会研究方法教程 (Social research method), 268-272. 北京: 北京 大学出版社

杨宜勇 (Yang Yiyong) (1997). 人力资源开发宏观层面和微观层面 (Macro- and micro- levels of human resource development). 中国人力资源开发, (6): 11-13

朱力, 王旭波, 徐展 (Zhu Li, Wang Xubo, Xu Zhan) (2003). 就业机会中的性别不平等 (Gender inequity in employment opportunity-The other side of relationship between market transition and inequity). 南京社会科学, (11): 70-72

张丹丹 (Zhang Dandan) (2004). 市场化与性别工资差异研究 (Marketization and gender wage differences). 中国人口科学, (1): 32-41 